\title{
Jogando para Aprender: Uma Pesquisa sobre a Influência do Jogo Black Stories nas Habilidades e Competências de Estudantes de Engenharia de Requisitos
}

\author{
Jorge Girão Limaverde Lima \\ Instituto Federal de Educação, Ciência \\ e Tecnologia do Ceará \\ Fortaleza, Ceará, Brasil \\ jorgelv11996@gmail.com
}

\author{
Andressa Bezerra Ferreira \\ Instituto Federal de Educação, Ciência \\ e Tecnologia do Ceará \\ Fortaleza, Ceará, Brasil \\ andressa.ferreira@ifce.edu.br
}

O desenvolvimento de software é uma atividade de crescente importância na sociedade contemporânea [1,2]. Visando melhorar a qualidade do software e aumentar a produtividade no processo de desenvolvimento, surgiu a Engenharia de Software (ES). Segundo [2], a Engenharia de Software é a disciplina de engenharia cujo foco está em todos os aspectos da produção de um software, desde os estágios iniciais até a sua manutenção. É dentro desse contexto que surge também a Engenharia de Requisitos (ER).

A Engenharia de Requisitos é o ramo da ES que estuda o conjunto de atividades e processos necessários para a elicitação, análise e especificação de requisitos. O processo associado à ER pode ser dividido, de forma simplificada, em três etapas.

A primeira etapa do processo é chamada de elicitação, ou descoberta de requisitos. A mesma consiste em reunir informações essenciais sobre o sistema a ser desenvolvido juntamente com os clientes e usuários finais do mesmo. Essas informações são comumente coletadas por meio do uso de entrevistas.

Uma vez finalizada a elicitação, é feita a análise dos requisitos, onde estes são classificados, organizados e priorizados. Por fim é realizada a especificação dos mesmos, onde serão documentados e adicionados ao Documento de Requisitos (DR).

O profissional responsável pela ER é chamado de Analista de Requisitos. Segundo [3], um bom analista de requisitos deve ter boa capacidade de abstração, comunicação e negociação. O profissional deve ser capaz de ouvir, questionar, compreender, e aprender as perspectivas dos stakeholders envolvidos. Ainda de acordo com [3], os profissionais com habilidades de abstração, observação e imersão são mais frequentemente incorporados ao mercado de trabalho.

Mediante esse contexto, este trabalho propõe uma discussão a respeito do Ensino e Aprendizagem na área de Engenharia de Requisitos, especificamente no tocante a Elicitação e/ou Descoberta de Requisitos.

\footnotetext{
Fica permitido ao(s) autor(es) ou a terceiros a reprodução ou distribuição, em parte ou no todo, do material extraído dessa obra, de forma verbatim, adaptada ou remixada, bem como a criação ou produção a partir do conteúdo dessa obra, para fins não comerciais, desde que sejam atribuídos os devidos créditos à criação original, sob os termos da licença CC BY-NC 4.0.

EduComp'21, Abril 26-30, 2021, Jataí, Goiás, Brasil (On-line)

(C)2021 Copyright mantido pelo(s) autor(es). Direitos de publicação licenciados à Sociedade Brasileira de Computação (SBC).
}

A proposta apresentada nesta pesquisa, envolve o uso do jogo Black Stories como instrumento de apoio ao Ensino e aprendizagem de Elicitação de Requisitos em salas de aula de Engenharia de Software.

Black Stories é um jogo de cartas para dois ou mais jogadores que tem como objetivo a solução de enigmas por meio de perguntas e respostas, semelhante a dinâmica que ocorre em uma entrevista [4].

A jogabilidade é simples. Na sua vez, o jogador compra uma das cartas do baralho e lê, na face da frente, o título e o texto de introdução do enigma em voz alta para os demais jogadores. A seguir, faz a leitura da solução do enigma, no verso da carta, em silêncio. Esta deve ser mantida em segredo. Então, a fim de decifrar o enigma, o grupo deve fazer perguntas para o jogador em posse da carta, que irá respondê-las apenas com: "Sim", "Não" ou "Irrelevante". O jogo termina quando o grupo de jogadores descreve o enigma em questão exatamente como apresentado no verso da carta.

Além da criatividade, jogadores de Black Stories apresentam habilidades de imersão, abstração e compartimentalização. O jogo estimula os envolvidos a visualizar os problemas por diferentes ângulos e imaginar possíveis desfechos e saídas. Vale salientar que essas e outras habilidades podem ser desenvolvidas e melhoradas à medida que se tem mais experiências com o jogo.

Com essas informações em mente, esta pesquisa buscará em sua continuidade, aplicar o jogo em salas de aula de Engenharia de Software, com o intuito de investigar se o mesmo contribui ou não para o desenvolvimento e aprimoramento de habilidades consideradas essenciais em bons analistas de requisitos.

\section{REFERÊNCIAS}

[1] Ariadne R. Carvalho; Thelma S. Chiossi. 2001. Introdução à engenharia de software. Campinas: Ed. da Unicamp. 2.]

[2] Ian Sommerville. 2011. Engenharia de Software. 9. ed. São Paulo: Pearson Education.

[3] Calazan s, A . Toffano Seidel, et al. O perfil do analista de requisitos de software: uma comparação entre a academia e o mercado de trabalho brasileiro. In: WE R 2017 .

[ 4] Machado, Italo. Conheça o jog o Black Stories e proponha atividades em sala de aula . Nota Terapia, 2019. Imagem. Disponível em: http://notaterapia.com.br/2019/12/04/conheca-o-jogo-black -stories-e-proponha - atividades-em-sala-de-aula/. Acesso em: 15 nov. 2020. 